\title{
Screening and Domestication of High Effective Microorganism Used in Oil Containing Wastewater Remediation
}

\author{
Xinyang XU, Xi CHEN, Yindi FAN \\ School of Resources and Civil Engineering, Northeastern University, Shenyang, China \\ E-mail: chenxineu@mail.neu.edu.cn \\ Received March 31, 2009; revised May 22, 2009; accepted May 25, 2009
}

\begin{abstract}
According to the characteristics of oil containing wastewater, four strains of microorganism, named TA-11, TA-17, HA-9, HD-1, were picked out from the oil contaminated soil and activated sludge of biochemical treatment system of an asphalt plant wastewater in Panjin. They can degrade oil and $\mathrm{COD}_{\mathrm{Cr}}$ in oil containing wastewater. The research result showed that each strain of microorganisms can remove oil and $\mathrm{COD}_{\mathrm{Cr}}$ in oil containing wastewater effectively when the $\mathrm{pH}$ value was 7.0, the temperature was 30 degree Celsius, the rotation speed was $140 \mathrm{r} / \mathrm{min}$ and the inoculation amount was $10 \%$. Especially the highest removal ratio of $\mathrm{COD}_{\mathrm{Cr}}$ was $68 \%$ after growth of 64 hours. The removal ratio of $\mathrm{COD}_{\mathrm{Cr}}$ in oil containing wastewater of mixed bacilli was much higher than that of unitary bacilli, and mixing a certain amount of domestic sewage with the oil containing wastewater will also improve the removal rate of $\mathrm{COD}_{\mathrm{Cr}}$.
\end{abstract}

Keywords: Oil Containing Wastewater, Screening, Domestication, $\mathrm{COD}_{\mathrm{Cr}}$, Removal Ratio

\section{Introduction}

The source of oily wastewater is very extensive, mainly including the oil industry, the oil processing, refining, storage and transportation, the emulsified oil waste water owing to the machinery manufacturing and processing, car washing in the transport industry, railway maintenance of the wash tank, and other oily waste water emissions of restaurants, food processing, textile industry and other manufacturing wastewater [1]. The main pollutant in oily wastewater is oil, as well as the sulfide, volatile phenol and so on.

According to the existing form of oil in the oily wastewater, it can be divided into floating oil, dispersed oil, emulsified oil, dissolved oil and so on. In the processing of oily wastewater, first of all, most of the floating oil, dispersed oil and emulsified oil are removed by physical or physical-chemical methods. And then biochemical method is used in further treatment. At last, the treated water was discharged after reaching standard [2-5]. However, the oily wastewater is poor biodegrad- ability, and problems such as running instability and low efficiency commonly exist in the bio-chemical process. Consequently, it is academic and practical significance that we should develop screening and domestication of microorganism which is used in oil containing wastewater remediation.

\section{Materrial and Methods}

\subsection{Experimental Strains}

Strains of microorganism used in the experiment were isolated from the oil contaminated soil and activated sludge of biochemical treatment system of an asphalt plant wastewater in Panjin. Four strains of microorganism, which can degrade oil and $\mathrm{COD}_{\mathrm{Cr}}$ of oil containing wastewater effectively, were obtained through screening and domestication [6-8]. In the laboratory they were named TA-11(short rod-like, yellow, gram positive bacteria), TA17 (globular, pink, gram positive bacteria) isolated and purified from the oil contaminated soil of Panjin 
Table 1. Water quality of oil containing wastewater sample (mg/L).

\begin{tabular}{ccccc}
\hline Oil & $\mathrm{COD}_{\mathrm{Cr}}$ & Sulfur & Phenol & $\mathrm{NH}_{3}-\mathrm{N}$ \\
\hline 63 & 1125 & 6.41 & 34.31 & 29.80 \\
\hline
\end{tabular}

asphalt plant and HA-9 (rod-like, yellow, gram positive bacteria), HD-1 (rod-like, pink, gram positive bacteria) from activated sludge of biochemical treatment system of an asphalt plant wastewater in Panjin.

\subsection{Experimental Wastewater Sample}

The oily wastewater is from biochemical treatment system of an asphalt plant wastewater in Panjin, of which the water quality is listed in Table 1.

\subsection{Screening and Domestication of Strains}

\subsubsection{Preliminary Screening Method of the Strains}

Through esterase decomposition test, strains which can highly degrade oil were screened out. Pick one purified strain, streak in prepared lipid culture medium, then put it into biochemical incubator with the temperature of 30 ${ }^{\circ} \mathrm{C}$, finally observe the color of medium after static culture for $64 \mathrm{~h}$. If it became red, it would suggest that the strain can degrade oil. The deeper the color showed, the stronger the ability of oil degradation was.

\subsubsection{Secondary Screening Method of Strains}

After obtaining strains in preliminary screening, secondary screening was based on ability of single strain degradation of COD in oil containing wastewater.

\subsubsection{Domestication Methods of Strains}

Domestication processes were divided into three phases. In the first phase, sterilized culture solution was filled into erlenmeyer flasks with $70 \mathrm{ml}$ in each, and inoculation amount in each erlenmeyer flask was $5 \mathrm{ml}$. They were cultivated in shaking cultivation at the speed of $130 \sim 140 \mathrm{r} / \mathrm{min}$, in the temperature of $30^{\circ} \mathrm{C}$ and for $72 \mathrm{~h}$. At the same time, the $\mathrm{OD}_{550}$ was measured every 6 hours. In the second phase, the condition was the same as first phase except that culture medium formula was different. In the third phase, sterilized culture solution was filled into the erlenmeyer flasks with $30 \mathrm{ml}$ in each, and Inoculation amount of each erlenmeyer flask was $2 \mathrm{ml}$. The culture condition was the same as the two phrases before.

\subsection{Determination of Growth Curve of Strains}

Turbidimetry was applied to determine concentration of bacterial suspension in order to decide the growth curve. $2 \mathrm{ml}$ of bacterial suspension was inoculated in newly prepared and sterilized basic culture medium, and cultivated in $30^{\circ} \mathrm{C}$. The $\mathrm{OD}_{550}$ was measured every $2 \mathrm{~h}$.

\subsection{Medium-Related}

Medium: beef extract $3 \mathrm{~g}$, peptone $10 \mathrm{~g}, \mathrm{NaCl} 5 \mathrm{~g}$, agar $15 \sim 20 \mathrm{~g}$, distilled water $1000 \mathrm{ml}, \mathrm{pH}$ value 7.0 7.2.

Oil medium: beef extract $3 \mathrm{~g}$, peptone $10 \mathrm{~g}, \mathrm{NaCl} 5 \mathrm{~g}$, agar $15 \sim 20 \mathrm{~g}, 90 \#$ diesel $1 \mathrm{ml}$, the concentration of $1.6 \%$ neutral red solution $1 \mathrm{ml}$, distilled water $1000 \mathrm{ml}, \mathrm{pH}$ value 7.0 7.2.

Domesticated medium: components of domesticated medium shown in Table 2.

Seed Media: glucose $12.5 \mathrm{~g}$, yeast extract $2.5 \mathrm{~g}$, $\mathrm{NH}_{4} \mathrm{NO}_{3} 1 \mathrm{~g}, \mathrm{MgSO}_{4} \cdot 7 \mathrm{H}_{2} \mathrm{O} 0.2 \mathrm{~g}, \mathrm{KCl} 0.2 \mathrm{~g}$, distilled water $1000 \mathrm{ml}, \mathrm{pH}$ value $7.0 \sim 7.2$.

Proliferated medium: glucose $30 \mathrm{~g}$, yeast extract $4 \mathrm{~g}$, beef extract $1 \mathrm{~g}, \mathrm{NH}_{4} \mathrm{NO}_{3} 1 \mathrm{~g}, \mathrm{MgSO}_{4} \cdot 7 \mathrm{H}_{2} \mathrm{O} 0.2 \mathrm{~g}, \mathrm{KCl}$ $0.2 \mathrm{~g}$, distilled water $1000 \mathrm{ml}, \mathrm{pH}$ value 7.0 7.2.

\subsection{Test Method of $\mathrm{COD}_{\mathrm{Cr}}$}

$\mathrm{COD}_{\mathrm{Cr}}$ in wastewater was determined by $\mathrm{COD}_{\mathrm{Cr}}$ instrument with the principle of potassium dichromate method.

\subsection{Test Method of $\mathrm{OD}_{550}$}

$\mathrm{OD}_{550}$ was determined by $722 \mathrm{E}$ spectrophotometer at $550 \mathrm{~nm}$ wavelength.

\section{Results and Discussion}

\subsection{Screening of Strains}

\subsubsection{Primary Screening of Strains}

Screen out the strains which can degrade the oil containing wastewater according to the esterase decomposition experiment. The result is shown in Table 3 .

Table 2. Culture medium component of high oil domesticating at different stages (g/L).

\begin{tabular}{cccccc}
\hline Stage of culture & diesel & yeast extract & $\mathrm{NH}_{4} \mathrm{NO}_{3}$ & $\mathrm{MgSO}_{4} \cdot 7 \mathrm{H}_{2} \mathrm{O}$ & $\mathrm{KCl}$ \\
\hline 1 & 1.0 & 3.0 & 1.0 & 0.2 & 0.2 \\
2 & 5.0 & 1.0 & 1.0 & 0.2 & 0.2 \\
3 & 10.0 & 1.0 & 1.0 & 0.2 & 0.2 \\
\hline
\end{tabular}


Table 3. Esterase decompound experiment.

\begin{tabular}{cccccc}
\hline Flat culture time & $12 \mathrm{~h}$ & $24 \mathrm{~h}$ & $36 \mathrm{~h}$ & $48 \mathrm{~h}$ & $64 \mathrm{~h}$ \\
\hline TA-11 & ++ & +++ & ++++ & ++++ & ++++ \\
TA-17 & ++ & ++ & +++ & ++++ & ++++ \\
TA-15 & + & ++ & ++ & +++ & ++++ \\
HA-9 & + & + & ++ & +++ & ++++ \\
HB-7 & - & + & ++ & +++ & +++ \\
HD-1 & - & - & + & ++ & +++ \\
HC-16 & - & - & + & + & ++ \\
TB-5 & - & - & - & + & + \\
TC-11 & - & - & - & + & + \\
HD-3 & - & - & - & + & + \\
\hline
\end{tabular}

(1): TA-11、TA-17、TA-15、TB-5、TC-11 are strains of microorganism separated from the oil contaminated soil of an asphalt plant in Panjin; HA-9、HB-7、HD-1、HC-16、HD-3 are strains of microorganism isolated from activated sludge of an asphalt plant in Panjin.

(2): The results were divided into five grades according to shade: $-、+、++,+++,++++$, the deeper of the colour, the stronger of the degradation ability.

(3): The 10 strains of microorganism which can degrade the oil were listed in the table above.

\subsubsection{Secondary Screening of Strains}

The secondary screening standard of the strains is the removal ability of $\mathrm{COD}_{\mathrm{Cr}}$.

We inoculated the single strain to the oil containing wastewater with the $\mathrm{pH}$ value 7.0 7.2 and rotation speed $140 \mathrm{r} / \mathrm{min}$ in $30^{\circ} \mathrm{C}$. After 72 hours' cultivation, $\mathrm{COD}_{\mathrm{Cr}}$ was determined. We performed the same experiment 3 times and the average result was shown in Figure 1.

In Figure 1, HA-9 has the highest $\mathrm{COD}_{\mathrm{Cr}}$ removal ratio of $50.3 \%$, the next is the strain named HD- $148 \%$, and then TA-11, TA-17, with the removal ratio of $44.8 \%$

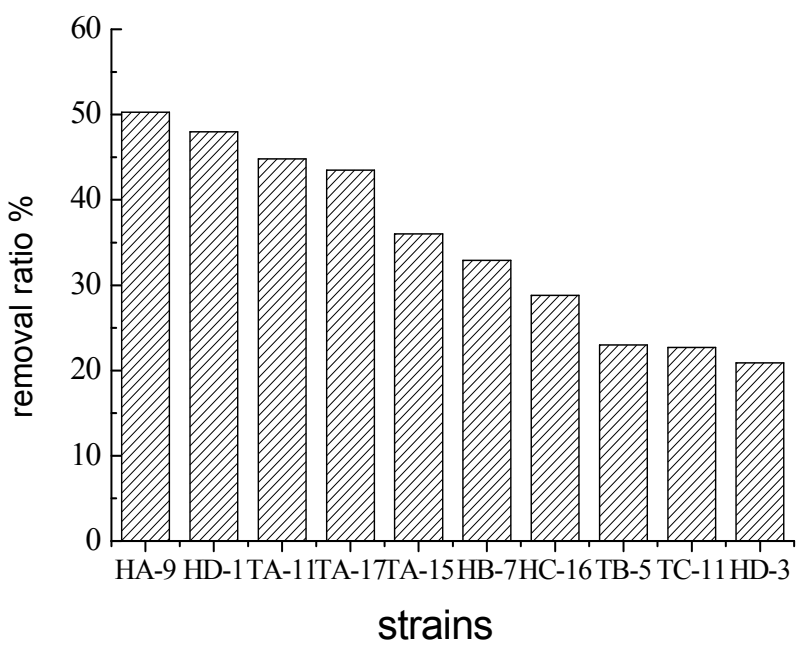

Figure 1. Variation of degradation ratios of pure strain.

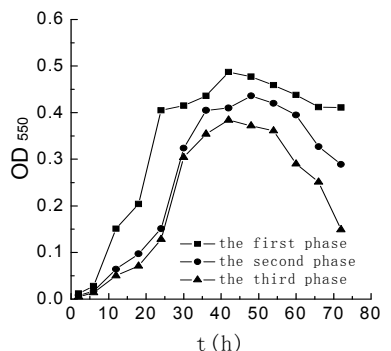

(a)

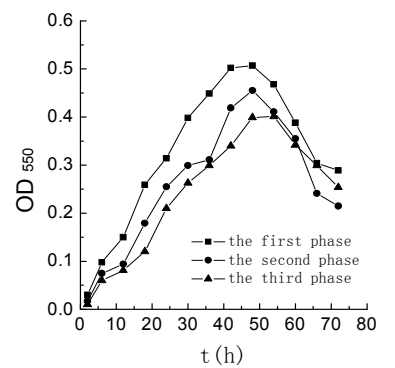

(c)

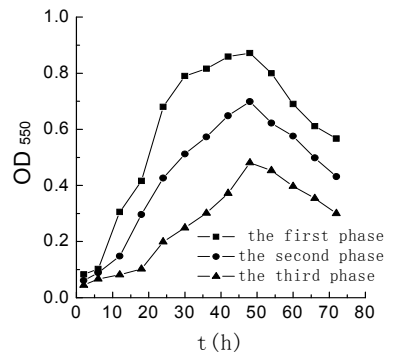

(b)

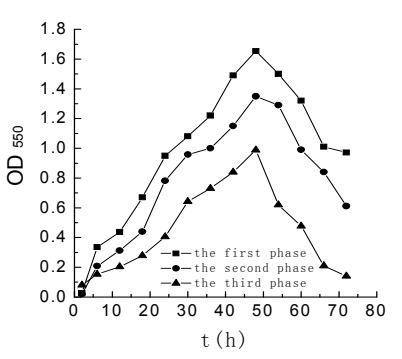

(d)
Figure 2. Result of high oil domesticating. (a)-TA-11; (b) - TA-17; (c)—HD-1; (d)—HA-9

and $43.8 \%$ respectively. Consequently, the four strains named HA-9、HD-1、TA-17 and TA-11 are chosen to domesticate in the following experiment.

\subsection{Taming of Stains}

4 strains selected were domesticated, of which the result is shown in Figure 2. 
In Figure 2, the value of the optical density $\mathrm{OD}_{550}$ reflects the number of bacteria in suspension, thereby reflecting the propagation of growth of microorganisms. According to the growth tendency, the number of bacteria reaches to the highest value within about $48 \mathrm{~h}$ with the extension of time, while the trend becomes slow after $48 \mathrm{~h}$. It indicates that strains have a good capacity for diesel degradation within a certain period of time, and can survive in high oil concentration.

\subsubsection{Morphological Characteristics and Growth Curve of Strains}

In beef extract peptone solid medium, TA-11 was yellow, transparent, smooth in surface, round uplift for the colony, and regular around. Cells were short rod-shaped, positive in gram stain when they were observed in the microscope.

In beef extract peptone solid medium, TA-17 was pink, opaque, smooth in surface, of round colonies, smaller, and regular around. Observed in the microscope, cells were spherical, positive in gram stain.

In beef extract peptone solid medium, HD-1 was pink, opaque, smooth in surface, of round colonies, regular of the edge. Observed in the microscope, cells were rodshaped, positive in gram stain.

In beef extract peptone solid medium, HA-9 yellow, deep color in center, opaque, of round colonies, regular around. Observed in the microscope, cells were rodshaped, positive in gram stain.

The morphology characteristics and growth curves of different strains are shown in Figure 3.

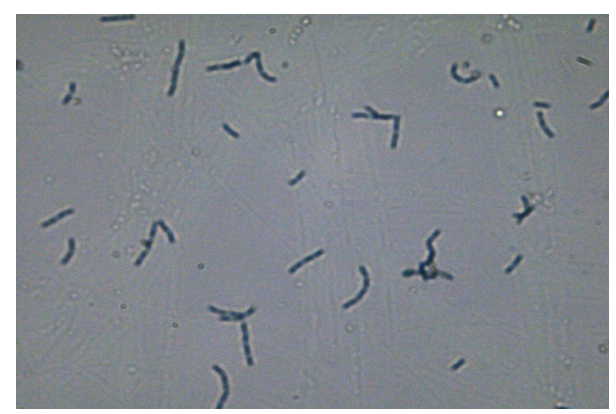

(a)

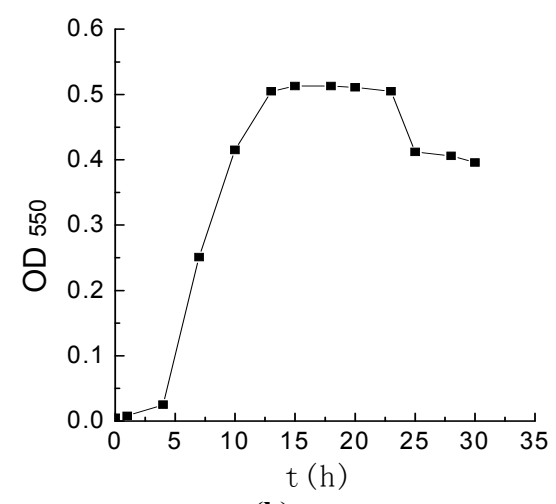

(b)

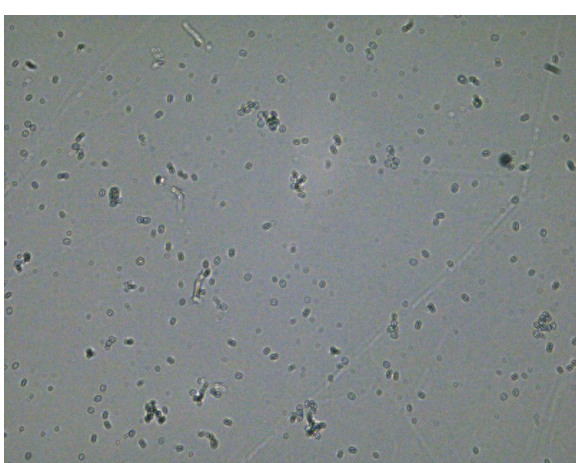

(c)

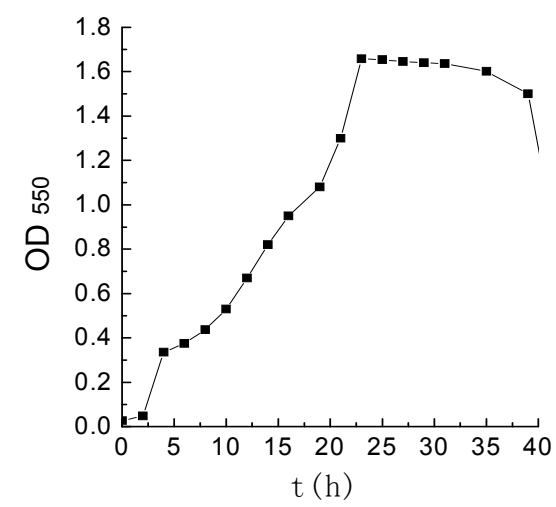

(d)

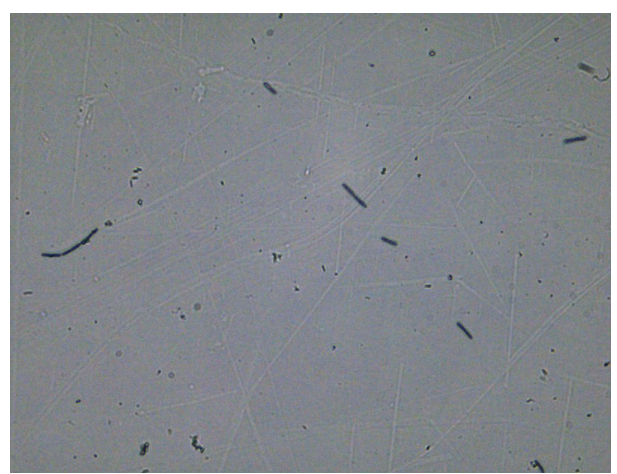

(e)

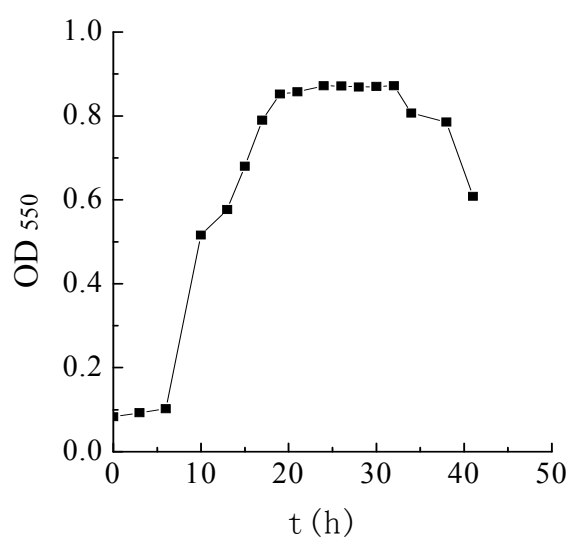

(f) 


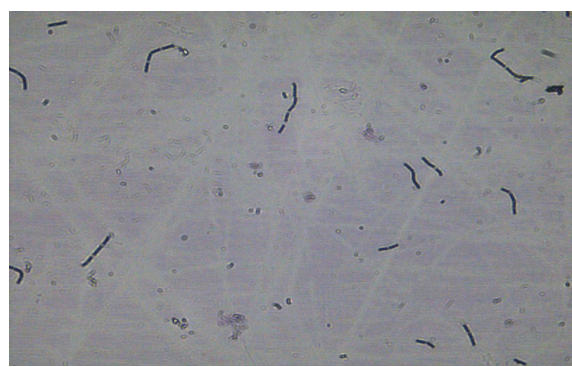

(g)

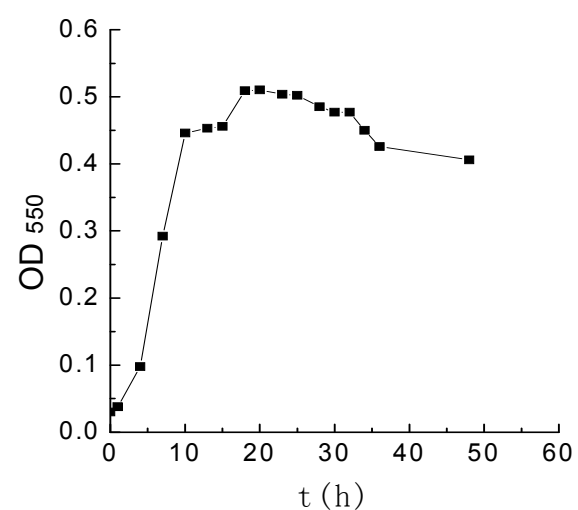

(h)

Figure 3. Micro photos and growth curves of microorganism. (a),(b)—TA-11; (c),(d)—TA-17; (e),(f)—HD-1; (g),(h)-HA-9

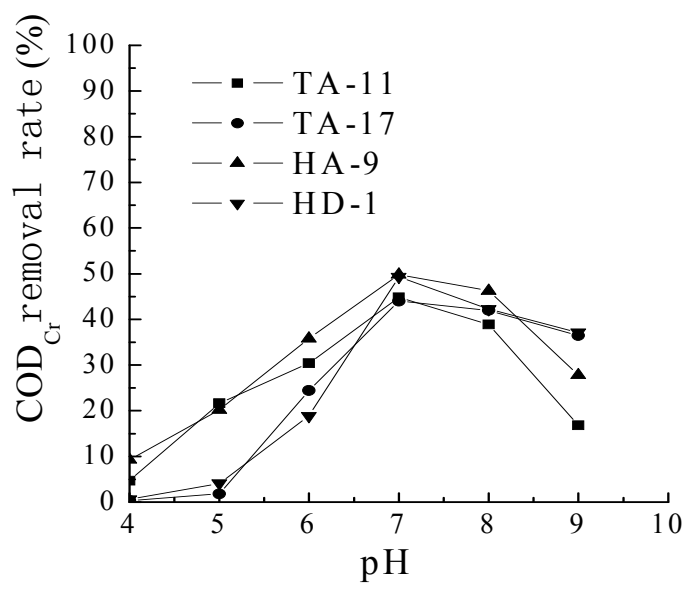

Figure 4. Influence of $\mathrm{pH}$ on $\mathrm{COD}_{\mathrm{Cr}}$ removal.

\subsection{The Influence of Environmental Factor on COD $_{\mathrm{Cr}}$ Removal Effect}

\subsubsection{The Influence of Original $\mathrm{pH}$ Value on $\mathrm{COD}_{\mathrm{Cr}}$ Removal Effect}

$\mathrm{PH}$ value has a great influence on living activity of microorganism. It mainly changes electric charge on the cell's membrane, thereby affecting microorganism's absorbability of nutriment; affects the enzyme's acting; transforms the acquirable ability of nutriment and the toxicity of injuring in their living circumstance. All kinds of microorganism have their own and optimal $\mathrm{pH}$ value.

In order to investigate the influence of original $\mathrm{pH}$ value on $\mathrm{COD}_{\mathrm{Cr}}$ removal effect, we took bacterium liquid $2 \mathrm{ml}$ from each single bacteria, put them into $50 \mathrm{ml}$ wastewater of different $\mathrm{pH}$ value respectively, cultivated them at $30{ }^{\circ} \mathrm{C}$ and rotate speed of shaking bed of $130 \mathrm{r} / \mathrm{min}$, and then measured the $\mathrm{COD}_{\mathrm{Cr}}$ removal ratio after $64 \mathrm{~h}$. The result is shown in Figure 4.

The optimal $\mathrm{pH}$ value range of four bacteria is 7-8. In this scope, their removal rates are high. When $\mathrm{pH}<5$, the removal efficiencies of $\mathrm{COD}_{\mathrm{Cr}}$ in the wastewater are very limited. When $\mathrm{pH}>8$, the removal efficiencies of all kinds of microorganism are obvious declined. The result shows that it is suitable for the four stains of bacteria to survive in a neutral condition, while it is not conducive to microbial growth and the degradation of oil in the condition of too high or too low $\mathrm{pH}$ value.

\subsubsection{The Influence of Temperature on $\mathrm{COD}_{\mathrm{Cr}}$ Removal Effect}

The principal part of wastewater treatment is kinds of microorganism which have special function. And their growth and propagating have consanguineous connections with the temperature. Microorganisms' growth is complicated biochemical reaction, which requires a certain range of temperature to perform in. The temperature range is wide (-10 95 degree Celsius), but each kind of microorganism can only growth in a definite range of temperature. In the range of the optimal temperature, microorganisms are vigorous physical activity, which conducts high treatment efficiency of the wastewater. And above or below this temperature range, it will injure microbial enzymatic systems, and affect the microorganisms' metabolism and the degradation of organic pollutants.

In order to investigate the influence of temperature on $\mathrm{COD}_{\mathrm{Cr}}$ removal effect, we took each single bacterium liquid, put them into $50 \mathrm{ml}$ wastewater with $\mathrm{pH}$ value about 7.0, cultivated them at different temperatures and rotate speed of shaking bed of $130 \mathrm{r} / \mathrm{min}$, and measured the $\mathrm{COD}_{\mathrm{Cr}}$ removal ratio after $64 \mathrm{~h}$. The result is shown in Figure 5.

As shown in Figure 5, when the scope of temperature is between 25 to 35 degree Celsius, removal ratios of these four bacterium are high. In conclusion, the optimal degradation temperature is 30 degree Celsius.

\subsubsection{The Influence of Inoculation Amount on COD $_{\mathrm{Cr}}$ Removal Effect}

In order to investigate the influence of inoculation amount on $\mathrm{COD}_{\mathrm{Cr}}$ removal effect, we took each single bacterium liquid of $1 \mathrm{ml}, 2.5 \mathrm{ml}, 5 \mathrm{ml}, 7.5 \mathrm{ml}, 10 \mathrm{ml}$, put them 


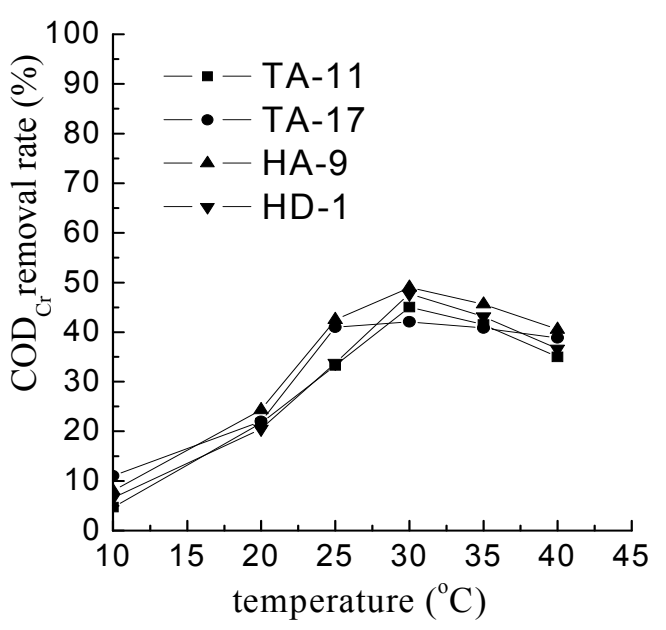

Figure 5. Influence of temperature on $\mathrm{COD}_{\mathrm{Cr}}$ removal.

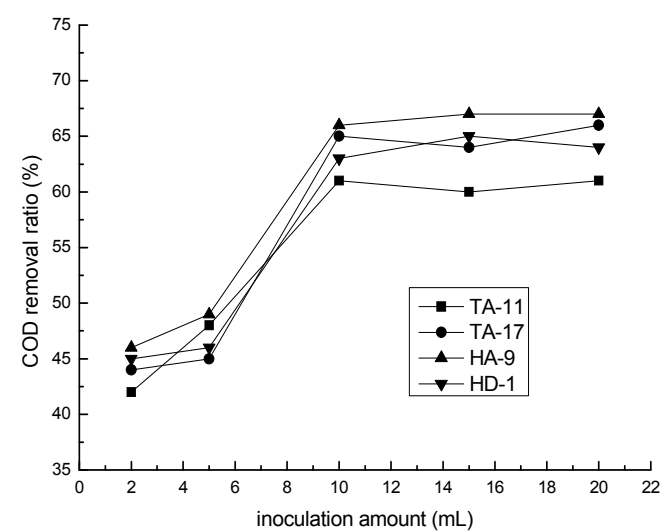

Figure 6. Influence of inoculation amount on $\mathrm{COD}_{\mathrm{Cr}}$ removal.

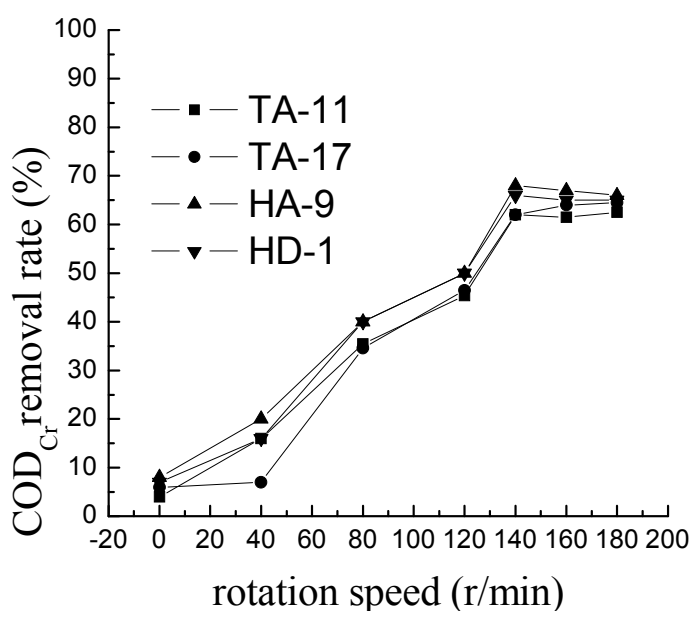

Figure 7. Influence of shaking rate on $\mathrm{COD}_{\mathrm{Cr}}$ removal.

into $50 \mathrm{ml}$ wastewater with $\mathrm{pH}$ value at about 7.0 , cultivated for $64 \mathrm{~h}$ at $30^{\circ} \mathrm{C}$ and rotate speed of shaking bed of $130 \mathrm{r} / \mathrm{min}$, and then measured the $\mathrm{COD}_{\mathrm{Cr}}$ removal ratio. The result is shown in Figure 6.
It can be seen that the less of inoculation amount, the higher concentration of residual $\mathrm{COD}_{\mathrm{Cr}}$. When the inoculation amounts are $2 \%$ and $5 \%$ respectively, the removal ratios of the 4 strains are less than $50 \%$. And when the amount is over $10 \%$, the influence on removal ratio is not obvious. Considering the economic benefit, $10 \%$ inoculation amount is optimal.

\subsubsection{The Influence of Aeration Intensity on COD $_{\text {Cr Removal Effect }}$}

The speed of shaking bed is used to represent aeration intensity in this experiment. We have investigate the influence of aeration intensity on $\mathrm{COD}_{\mathrm{Cr}}$ removal effect at the range of $0 \sim 180 \mathrm{r} / \mathrm{min}$.

We chose each single bacterium liquid, put them into $50 \mathrm{ml}$ wastewater with $\mathrm{pH}$ value about 7.0 , in the 30 degree Celsius temperature conditions, cultivated them at the speed of $0,40,80,120,140,160$ and $180 \mathrm{r} / \mathrm{min}$ respectively for $64 \mathrm{~h}$. At last, we contrasted the $\mathrm{COD}_{\mathrm{Cr}}$ removal ratios in the wastewater of different bacterium liquids at different speeds. The result is shown in Figure 7.

As the result shown in Figure 5, with the increase of speed, $\mathrm{COD}_{\mathrm{Cr}}$ removal ratios in the oil containing wastewater are in upward trend. When the speed is at $140 \mathrm{r} / \mathrm{min}$, the $\mathrm{COD}_{\mathrm{Cr}}$ removal ratios are the highest, especially the removal ratio of HA- 9 can be $68 \%$.

\subsubsection{The Influence of Mix-Bacterium on $\mathrm{COD}_{\mathrm{Cr}}$ Removal Effect}

We took $5 \mathrm{ml}$ bacterium liquid of each bacterium, put all of them into $50 \mathrm{~mL}$ wastewater with $\mathrm{pH}$ value about 7.0 in the 30 degree Celsius temperature conditions, cultivated them for $64 \mathrm{~h}$ at the speed of $140 \mathrm{r} / \mathrm{min}$. At last, we measured $\mathrm{COD}_{\mathrm{Cr}}$ removal ratios which changed with time, and compared with the equivalent single-strain vaccine. The result is shown in Figure 8. As shown, the removal ratio of the mix of efficiency is higher than that of each single stain.

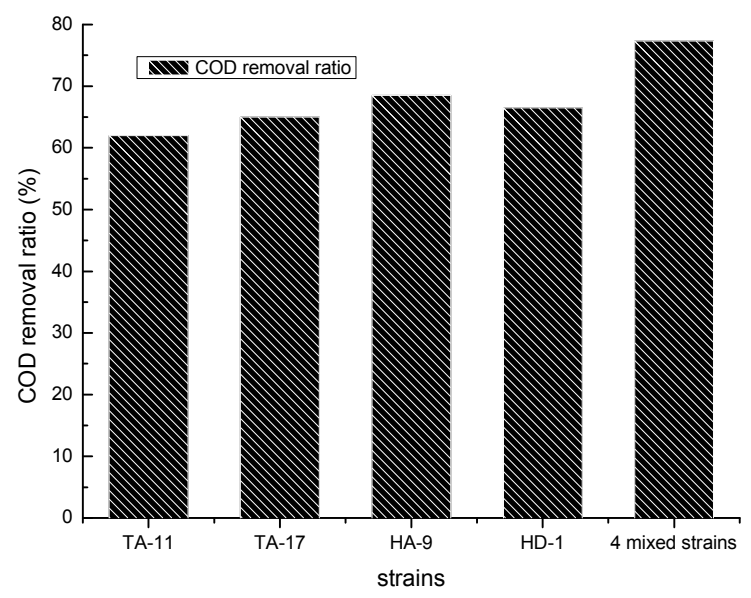

Figure 8. Removal ratio of $\mathrm{COD}_{\mathrm{Cr}}$ for mixed bacilli. 
Table 4. Comparation of the removal ratios of $\mathrm{COD}_{\mathrm{Cr}}$.

\begin{tabular}{ccccccc}
\hline \multirow{2}{*}{ Strains } & TA-11 & TA-17 & HA-9 & HD-1 & 4 mixed strains \\
\hline \multirow{2}{*}{ Removal ratio } & Add nutriments & 74 & 76 & 80 & 78 & 88 \\
\cline { 2 - 7 } & No add & 60 & 65 & $68 C$ & 67 & 78 \\
\hline
\end{tabular}

\subsubsection{The Influence of Nutriment on $\mathrm{COD}_{\mathrm{Cr}}$ Removal Effect}

It is not only enough organic matters, but also many kinds of well-proportioned nutriment that are required in the growth of microorganism, including $\mathrm{C}, \mathrm{N}, \mathrm{P}, \mathrm{S}$ and many microelements such as $\mathrm{K}, \mathrm{Ca}, \mathrm{Mg}, \mathrm{Fe}$ and vitamins. Domestic sewage can meet the requirement. As a result, domestic wastewater which was simulated with compounds of $0.4 \% \mathrm{NH}_{4} \mathrm{NO}_{3}, 0.8 \% \mathrm{~K}_{2} \mathrm{HPO}_{4}, 0.8 \% \mathrm{KH}_{2} \mathrm{PO}_{4}$, $0.1 \% \mathrm{MgSO}_{4} \cdot \mathrm{H}_{2} \mathrm{O}$ and distilled water with $\mathrm{pH}$ value around 7 is added to the oil containing water in this experiment. Their proportional is $1: 1$, and $\mathrm{COD}_{\mathrm{Cr}}$ of the mixed wastewater is $850 \mathrm{mg} / \mathrm{L}$. We added $10 \%$ of total inoculation amount, and $2.5 \%$ of inoculation amount of each single bacterium, into the mixed wastewater, and cultivated them in $30^{\circ} \mathrm{C}$, at rotate speed of shaking bed of $140 \mathrm{r} / \mathrm{min}$ for $64 \mathrm{~h}$. Compared with the wastewater which is diluted as twice of the original, we investigated the removal ratio of $\mathrm{COD}_{\mathrm{Cr}}$ of immobilized bacterium. The result is shown in Table 4.

The result shows that the removal ratios of each strain have increased after $64 \mathrm{~h}$. So it is helpful to improve the removal effect if a certain amount of domestic sewage is added into the oil containing wastewater in practical treatment.

\section{Conclusions}

1) We have separated four objective stains of bacterium which have high efficiencies on removal of oil and $\mathrm{COD}_{\mathrm{Cr}}$ in the oil containing wastewater from soil polluted by heavy oil and activated sludge biochemical treatment system of an asphalt plant wastewater in Panjin. And they are named in the laboratory: TA-11, TA-17, HA-9 and HD-1. It is observed in the microscope that the four stains of bacterium are gram-positive.

2) The biochemical degradation tests on the oil containing wastewater show that the treatment effects of each stain are best when the $\mathrm{pH}$ value is 7.0 , the rotation speed $140 \mathrm{r} / \mathrm{min}$, the inoculation amount $10 \%$ and the temperature of circumstance 30 degree Celsius. And after $64 \mathrm{~h}$ 's cultivation, the $\mathrm{COD}_{\mathrm{Cr}}$ removal ratio can reach approximately $68 \%$ of single bacterium. The $\mathrm{COD}_{\mathrm{Cr}}$ removal efficiency of the mix stains is higher than that of any single stain.

3 ) It is mixing a certain amount of domestic sewage with the oil containing wastewater that will also improve the removal efficiency of $\mathrm{COD}_{\mathrm{Cr}}$ in practical treatment.

\section{References}

[1] S. B. Hou, X. M. Xuan, "Status of research and application of the oily wastewater treatment technology [J]," Shanghai Chemical Industry, Vol. 9, pp. 11-14, 2003.

[2] T. Berrin, "Microscopic characterization of oil droplets removed by flocs after coagulation of oil-water emulsions [J]," Journal of Environmental Science and Health, Vol. 37, No. 2, pp. 127-138, 2002.

[3] A. M. A. Omar, "Recovery of residual emulsifiable oil from wastewater by flotation lubrication science [J]," Water Science Technology, Vol. 14, No. 2, pp. 275-284, 2002.

[4] D. D. Qian, L. J. Xu, and J. W. Shi, "Study on high-strengh oil-containing wastewater treatment attached yeasts [J]," Energy Environmental Protection, Vol. 23, No. 1, pp. 41-45, 2009.

[5] G. Q. Liu, J. W. Shen, and C. K. Gao, "Study on treatment oil wastewater by screening high efficicent degradation bacteria of crude oil [J]," Technology of Water Treatment, Vol. 34, No. 10, pp. 26-29, 2008.

[6] G. Yang, "A Course of microbiology experiment [M]," Science press, pp. 15-25, 2004.

[7] X. Y. Xu, Y. Zhang, and H. B. Li, "Immobilization process of flavobacterium sp. for bioremediation of contaminated surface water $[\mathrm{J}]$," Journal of Northeastern University: Natural Science, Vol. 8, pp. 783-786, 2005.

[8] X. Y. Xu, Y. Zhang, and H. B. Li, "Chemical embedding immobilization technique of micrococcus sp. used in contaminated surface water remediation [J]," Journal of Northeastern University: Natural Science, Vol. 1, pp. 1146-1149, 2006. 